\title{
PODEJŚCIE INTERPRETACYJNE W NAUCE O POLITYCE - OMÓWIENIE 4. NUMERU „TEORII POLITYKI”
}

\author{
Kamil Aksiuto \\ Uniwersytet Marii Curie-Skłodowskiej w Lublinie \\ Wydział Politologii i Dziennikarstwa \\ ORCID ID: https://orcid.org/0000-0002-4768-8936 \\ e-mail: kamaks@poczta.umcs.lublin.pl
}

\begin{abstract}
Streszczenie: Artykuł poświęcony jest omówieniu 4. numeru czasopisma naukowego „Teoria Polityki”, który ukazał się w 2020 r. Każdy numer tego czasopisma posiada temat przewodni. Artykuły zebrane w numerze 4. „Teorii Polityki” objaśniają i egzemplifikują różne warianty podejścia interpretacyjnego rozumianego jako ogólny model uprawiania nauki o polityce.
\end{abstract}

Słowa kluczowe: hermeneutyka, interpretacja, nauki o polityce, wyjaśnienie

W uprawianiu nauki wiele kwestii zostaje przesądzonych przez obrany punkt wyjścia. Ten zaś z kolei jest jednocześnie zawsze związany z pewnymi filozoficznymi rozstrzygnięciami [Bachryj-Krzywaźnia 2016: 127]. Pochodną tych rozstrzygnięć jest sposób ujęcia celu dociekań, przyjęte standardy naukowości, właściwe metody prowadzenia badań itp. Wszystkie te twierdzenia potwierdza w moim przekonaniu 4. numer czasopisma naukowego „Teoria Polityki”, który ukazał się w roku 2020. Poświęcony jest on bowiem roli, jaką w nauce o polityce odgrywa interpretacja, oraz podejściu interpretacyjnemu jako pewnemu dystynktywnemu modelowi uprawiania tej dyscypliny.

Warto nadmienić, że każdy numer „Teorii Polityki” przygotowywany jest przez grono pracowników innego uniwersytetu. Za przygotowanie 4. numeru czasopisma odpowiadał Zakład Teorii Polityki Uniwersytetu im. Adama Mickiewicza w Poznaniu. Zebrane w nim artykuły dotykają wielu zagadnień. Nie jest możliwe, abym w niniejszym tekście przedstawił je wszystkie w sposób czyniący zadość ich złożoności. Skazany jestem więc na pewną selektywność. Postaram się też krótko nakreślić tło, w którym należy osadzić kwestie powracające w wielu artykułach, które weszły do omawianego numeru. 
Rozwój nowoczesnej nauki zwykło się wiązać z odrzuceniem arystotelesowskiego schematu poznawczego. Kluczową rolę w wywodzącym się od Stagiryty ujęciu nauki odgrywało poznanie przyczyn celowych rzeczy. Jednakże począwszy od przełomu XVI/XVII stulecia, arystotelizm stopniowo wypierany jest przez nowy, mechanistyczny model wiedzy naukowej. Obywa się on bez pojęcia przyczyny celowej - wyjaśnić jakieś zjawisko znaczy dociec jego przyczyn sprawczych, które powinny być możliwe do zaobserwowania zmysłowo [Czajowski 2020: 45-46]. Sukces opartych na tym ujęciu nauk przyrodniczych, mierzony przede wszystkim ogromnym wzrostem zakresu ludzkiej kontroli nad naturą, jaki za jego sprawą stał się możliwy, doprowadził do sformułowania w XIX wieku w pełni konsekwentnego stanowiska pozytywistycznego. Pozytywizm zakładał, że nauki o człowieku nie różnią się zasadniczo od przyrodniczych co do przedmiotu (gatunek ludzki jest wszak częścią natury) ani stosowanych procedur badawczych. Interpretację traktował on zaś jako zjawisko nienaukowe, niedorastające do rygorystyczności i obiektywności wiedzy z prawdziwego zdarzenia ${ }^{1}$. Nie trzeba było jednak długo czekać na antypozytywistyczną reakcję. Jej reprezentanci, pomimo licznych dzielących ich różnic, podkreślali swoistość nauk społecznych i humanistycznych, których przedmiot nie daje się właściwie badać metodami przyrodoznawstwa. Odmienność ta wynika z tego, że w naukach, które w języku niemieckim zwykło się kiedyś określać mianem Geisteswissenschaften, nie idzie o przyczynowe wyjaśnienie działań, a o rozumienie, wniknięcia w struktury sensu, znaczenia, które są konstytutywne dla ludzkich działań i praktyk. Krótko mówiąc, konieczne jest dokonywanie interpretacji ${ }^{2}$. Podejście interpretacyjne miało wielu prekursorów i twórców, m.in.: Wilhelma Diltheya, Edmunda Husserla, Martina Heideggera, Maxa Webera, Hansa-Georga Gadamera - to chyba najczęściej powtarzające się nazwiska. Wśród bardziej nam współczesnych jego eksponentów wymienia się m.in.: Clifforda Geertza, Anthony'ego Giddensa, a nawet Michela Foucault i Jacques'a Derridę. Także pozytywizm ma swoich następców w naukach społecznych. Behawioryści, instytucjonaliści, zwolennicy teorii racjonalnego wyboru kierują się pewnymi milcząco przyjętymi założeniami pozytywistycznej metodologii [Bevir, Rhodes 2016: 6-9]. Spór pomiędzy pozytywizmem i podejściem interpretacyjnym wciąż jest zatem żywy w naukach społecznych. W niektórych dyscyplinach, na przykład w stosunkach międzynarodowych, swego rodzaju „zwrot interpretacjonistyczny” jest zjawiskiem stosunkowo świeżym, poprzedzonym wieloletnią dominacją pozytywistycznych wzorców. Stąd też rewersem wzrostu zainteresowania podejściem interpretacyjnym jest swego rodzaju

1 Na podobieństwo pomiędzy założeniami pozytywizmu a kartezjańskim schematem epistemologicznym, w którym chodzi o zdobycie wiedzy pewnej, możliwej dzięki rygorystycznemu rozdzieleniu podmiotu i przedmiotu poznania, zwrócił uwagę M. Bachryj-Krzywaźnia [zob. Bachryj-Krzywaźnia 2016: 128-129].

2 Opis niemieckiego kontekstu debaty między pozytywizmem i obrońcami autonomii $G e-$ isteswissenschaften na przełomie XIX i XX wieku przedstawił R.L. Anderson [zob. R.L. Anderson 2008: 221-234]. 
kartezjański lęk [Kurowska 2020: 104]. Do głosu dochodzą obawy przed subiektywizmem lub relatywizmem, przed utratą przez wiedzę naukową uprzywilejowanego statusu (a co za tym idzie, przed utratą przez naukowców ich społecznej pozycji) oraz przed ideologizacją nauki.

Po wprowadzającym do numeru tekście autorstwa Zbigniewa Bloka i Małgorzaty Kołodziejczak zamieszczony został artykuł Andrzeja W. Jabłońskiego. Autor przedstawił różne znaczenia terminu ,interpretacja”, które są wpisane w teoretyczne i metodologiczne konteksty uprawiania wielu nauk społecznych, m.in. etnografii, filozofii, historii, socjologii, prawa i nauk o polityce. Postawione zostały przez niego także dwa kluczowe problemy, z którymi uporać się musi podejście interpretacyjne. Pierwszy z nich to problem doprecyzowania wzajemnych relacji między interpretacją, rozumieniem i wyjaśnieniem. Do tego zagadnienia jeszcze powrócę. Drugi zaś jest związany z mnogością interpretacji, jakim można poddać właściwie każde zjawisko. Czy oznacza to, że nie ma żadnych kryteriów pozwalających nam wskazać interpretacje prawdziwe lub przynajmniej lepsze od innych? Autor wskazał wiele takich tropów, w jakiejś mierze stosowanych przez społeczność badaczy, które pozwalają na identyfikację interpretacji lepszych, bardziej wiarygodnych od innych [Jabłoński 2020: 19-20]. Pozostaje jednak pytanie, czy nawet po zastosowaniu tych standardów wyższość niektórych interpretacji wskazuje na coś więcej niż to, że są one w danym momencie za takie uznawane przez większość badaczy?

Podobne wątki odnajdziemy w artykule Małgorzaty Kułakowskiej. Zwraca ona uwagę na sposób, w jaki wybory metodologiczne są powiązane, nie zawsze świadomie, z przyjęciem pewnych rozstrzygnięć ontologicznych. Zaletą tego tekstu jest również wydobycie różnorodności teorii i stanowisk, które są obejmowane wspólną ramą podejścia interpretacyjnego w naukach społecznych [Kułakowska 2020: 32-34]. Globalne kontrastowanie ich z pozytywizmem, skądinąd zrozumiałe, może przyczyniać się do zacierania istotnych różnic pomiędzy nimi. Na uwagę zasługują także fragmenty artykułu Kułakowskiej, które są poświęcone całej palecie możliwych metodologicznych implikacji podejścia interpretacyjnego [Kułakowska 2020: 36-40].

Artykuł Andrzeja Czajowskiego przynosi najpełniejsze w całym tomie omówienie historycznej genezy podejścia interpretacyjnego oraz jego sporu z pozytywizmem. Autor wszakże nie postrzega jednak tego agonu jako nieprzezwyciężalnego. Opowiada się za tym, że oprócz wyjaśnienia empirycznego istnieje również wyjaśnienie interpretacyjne (rozumiejące, humanistyczne). Czajowski wydaje się podzielać przeświadczenie historyka Jerzego Topolskiego o tym, że rozumienie nie jest jakimś odrębnym rodzajem wyjaśnienia, a raczej globalnym efektem wyjaśnienia integralnego, łączącego w sobie wyjaśnienie empiryczne i interpretacyjne [Czajowski 2020: 49-50]. W tym kontekście pojawia się również propozycja Tadeusza Klementewicza, adaptująca koncepcję wyjaśnienia integralnego do nauki o polityce. Wymaga ono z jednej strony intencjonalnego wyjaśnienia działań podmiotów politycznych (ich celów, przekonań, wiedzy itp.), 
z drugiej zaś - przyczynowego wyjaśnienia skutków tychże działań [Czajowski 2020: 50-51]. W konkluzji artykułu Czajowski opowiada się za tym, aby w nauce o polityce starać się w miarę możliwości łączyć ze sobą oba rodzaje wyjaśnień.

Filip Pierzchalski skrytykował z kolei w swoim artykule solipsyzm metodologiczny. Jeśli dobrze rozumiem intencje autora, to jednym z jego celów jest wykazanie, że nieuzasadnione są zarzuty pod adresem podejścia interpretacyjnego, iż musi ono prowadzić do skrajnej subiektywizacji procesu badawczego. Nie wdając się w szczegółową charakterystykę solipsyzmu metodologicznego, można przyjąć, iż czyni on aktywność naukową wyrazem indywidualnych stanów psychicznych badacza i właściwego mu ,prywatnego języka”. Pierzchalski wykorzystuje do wykazania aporyczności tego stanowiska krytykę z perspektywy ujęcia eksternalistycznego rozwijanego między innymi przez Hillary'ego Putnama. Rezultatem tych dociekań jest wskazanie na obiektywizującą (może lepiej byłoby powiedzieć - intersubiektywizującą) rolę konkretnej wspólnoty badaczy, która ustala znaczenia pojęć naukowych, a ujmując sprawę jeszcze szerzej, „na społeczny charakter poznania naukowego" [Pierzchalski 2020: 74]. Są to cenne spostrzeżenia, tym bardziej więc szkoda, że znalazły się one w tekście napisanym bardzo hermetycznym, scjentystycznym językiem.

W niezwykle ciekawym artykule Bartosza Brożka za punkt wyjścia służy zjawisko, które w języku angielskim określa się mianem embodied cognition. $\mathrm{W}$ dużym uproszczeniu termin ten oznacza, że procesy poznawcze uzależnione są od różnych modalności funkcjonowania ludzkiego ciała. Badania mózgu dowodzą na przykład, że rozumienie języka jest związane z aktywacją tych samych grup neuronów co w przypadku percepcji, wykonywania jakiejś czynności czy wyobrażania jej sobie [Brożek 2020: 80-82]. Jaki ma to jednak związek z interpretacją? Otóż mechanizm wyobrażania sobie pozwala wyjaśnić rozumienie terminów odnoszących się do konkretnych przedmiotów, np. młotek - nie wyjaśnia on jednak powstawania i rozumienia pojęć abstrakcyjnych. Brożek identyfikuje trzy narzędzia wykorzystywane przez nas do interpretowania abstrakcyjnych terminów: egzemplifikację, parafrazę i osadzenie (embedding) [Brożek 2020: 86-87]. Łącznie tworzą one teoretyczne rusztowanie, które może posłużyć ulepszeniu praktyk interpretacji prawa ${ }^{3}$.

3 Chciałbym poczynić dwie marginesowe uwagi, które w niczym nie zmieniają bardzo pozytywnej oceny artykułu Pawła Brożka. Nie jest do końca trafne stwierdzenie autora, że Arystoteles utożsamia zakres pojęcia „człowiek” z każdym racjonalnym zwierzęciem. W księdze VI Etyki Nikomachejskiej Arystoteles przyznał, że niektóre gatunki zwierząt również posiadają pewne władze rozumowe, np. cechuje je rozsądek, roztropność (phronesis) [zob. Arystoteles 2007: 199]. Brożek stwierdził również, że wszystkie cztery sformułowania imperatywu kategorycznego przedstawione przez Kanta są równoważne. Tak niewątpliwie twierdził sam filozof z Królewca. Jeśli jednak idzie o równoważność znaczenia, to nie wszyscy interpretatorzy Kanta podzielają ten pogląd. Jednym z zarzutów wysuwanych pod adresem filozofii moralności Kanta jest właśnie to, że błędnie utożsamił on ze sobą różne sformułowania imperatywu, zob. R. Johnson, A. Cuerton, Kant's Moral Philosophy, https://plato.stanford.edu/entries/kant-moral/ [dostęp: 25.07.2020]. 
Artykuł Xymeny Kurowskiej zwraca uwagę zarówno na obietnicę emancypacji, jaką niosło (i zapewne wciąż niesie) ze sobą zastosowanie podejścia interpretacyjnego w badaniu stosunków międzynarodowych, jak i na podejrzliwy chłód, który często jest reakcją na ten sposób uprawiania tej dyscypliny. Autorka wskazała wyróżniki interpretacyjnego wzorca „produkcji wiedzy”, zaliczając do nich m.in.: monizm ${ }^{4}$, nasycenie faktów wartościami (value laden facts), niedookreśloność (indeterminacy) języka, abdukcyjną logikę dociekań i refleksyjność teoretyka, która przeciwstawiana jest hołubionej przez pozytywistów neutralności i obiektywności [Kurowska 2020: 95-100]. W artykule można również odnaleźć opis dokonań czołowych badaczy wpisujących się w podejście interpretacyjne w stosunkach międzynarodowych, takich jak: Cecelia Lynch, Felic Ciuta, Antje Wiener, Lee Anne Fujii [Kurowska 2020: 101-104].

Czy teoria polityki jest nieuchronnie powiązana z dokonywaniem interpretacji? Janusz Węgrzecki w swoim artykule odpowiada na to pytanie twierdząco. $\mathrm{Na}$ interpretowanie jego zdaniem skazane są zarówno empiryczne, jak i normatywne teorie polityki. Teoretyk polityki nie funkcjonuje w poznawczej próżni, jego dociekania są ukierunkowane przez podejście badawcze, które przyjmuje, ale także uwikłane w ideologiczne przekonania. Przede wszystkim jednak zakładają one pewne ogólne rozstrzygnięcia dotyczące natury racjonalności i prawdy, antropologii, aksjologii i teorii społeczeństwa [Węgrzecki 2020: 112]. Tego typu przesądzenia nie zawsze są wyrażone explicite, ale nie umniejsza to ich roli w aktywności naukowej. Ich rozwinięcie w ramach konkretnej teorii jest zawsze pewną interpretacją. Węgrzecki opowiada się w dalszej części swojego tekstu za rozumieniem interpretacji jako rekonstrukcji oraz sam stara się zaproponować rekonstrukcję perspektywy badawczej personalizmu, w której centralne miejsce zajmuje idea godności człowieka [Węgrzecki 2020: 115-120]. Chciałem zwrócić uwagę na dwie kwestie, które odróżniają Węgrzeckiego od wielu zwolenników podejścia interpretacyjnego. Po pierwsze, jest on mniej przychylnie nastwiony do filozofii hermeneutycznej [Węgrzecki 2020: 111]. Po drugie zaś nieuchronność interpretacji nie wyklucza zdaniem Węgrzeckiego tego, że celem poznania jest prawda rozumiana w klasyczny sposób, jako adekwatność umysłu do rzeczy [Węgrzecki 2020: 115].

Hans-Georg Gadamer, najważniejszy reprezentant filozoficznej hermeneutyki w wieku XX, to główny bohater artykuły Dietricha Teicherta. Autor skupił się na próbie rewindykacji niektórych wątków filozofii Arystotelesa przez Gadamera. Przede wszystkim chodzi o wiedzę praktyczną, którą Gadamer, idąc w ślady Stagiryty, odróżnił zarówno od wiedzy teoretycznej (episteme), jak i technicznej (techne). Wiedza praktyczna dotyczy dobrego życia i wymaga posiadania cnoty roztropności (phronesis) [Teichert 2020: 126-128]. Nie poddaje się ona przekładowi na uniwersalne reguły, nie pozwala na pełne zdystansowanie się podmiotu wobec konkretnych okoliczności, w których przyszło mu działać, ma

\footnotetext{
4 Być może lepsze byłoby w tym kontekście określenie „holizm”, a nie „monizm”.
} 
nieuchronnie kontekstualny i dialogiczny charakter. Teichert dostrzegł nić biegnącą od wczesnych pism Gadamera, przez jego najważniejsze dzieło Prawda i metoda, aż po jego późne pisma. Łączy ona właśnie arystotelesowską koncepcję wiedzy praktycznej ze sprzeciwem niemieckiego filozofa wobec coraz bardziej dominującej w nowoczesnej kulturze obsesji znalezienia jednej metody umożliwiającej zapanowanie nad całym światem (naturalnym i społecznym) dzięki technologii. Tym uniformizującym, scjentystyczno-technologicznym zapędom Gadamer przeciwstawił hermeneutyczną koncepcję rozumienia i interpretacji. Podobnie jak w przypadku arystotelesowskiej wiedzy praktycznej mają one dialogiczną, deliberacyjną strukturę, uwarunkowane są przez język, kulturę, tradycję [Teichert 2020: 131-136]. Nie da się więc ich też zawrzeć w gotowym zestawie zasad dostosowanych do każdej sytuacji. Niezmiernie ciekawe byłoby bliższe przyjrzenie się politycznym implikacjom tego ujęcia, na co w artykule nie starczyło już jednak niestety miejsca.

Z kolei artykuł Jana P. Hudzika stanowi próbę pewnej, bardzo życzliwej interpretacji dekonstrukcyjnej teorii polityki. Hudzik zaznaczył, że myśliciele, tacy jak Michel Foucault czy Jacques Derrida, w latach 70. minionego stulecia znaleźli się w niezbyt godnej pozazdroszczenia sytuacji. Z jednej strony ówczesna akademicka ortodoksja nie oferowała teorii operującej językiem adekwatnym do tego, aby opisać aktualne napięcia społeczne i polityczne. $Z$ drugiej zaś skompromitowały się zarówno radziecki komunizm, jak i liberalizm, ten ostatni, jeśli dobrze rozumiem tok wywodu, głównie za sprawą ekonomistów, takich jak Milton Friedman, oraz polityków ochoczo realizujących ich idee, vide Margaret Thatcher, Ronald Reagan i Augusto Pinochet [Hudzik 2020: 143-144]. Francuscy teoretycy próbowali przezwyciężyć ten impas, tworząc nowatorską teorię władzy. Ich niewątpliwą zasługą było dostrzeżenie, że władza nie ma tylko jurydycznego charakteru, że jej istnienie nie przejawia się tylko w przymusie stosowanym przez instytucje państwa. Mało tego, władza nie zawsze jest represywna, w swych bardziej perfidnych formach staje się produktywna, kusi obietnicą wolności, podczas gdy tak naprawdę coraz bardziej wikła nas w swoje mechanizmy [Hudzik 2020: 152-154]. Władza znajduje swoje „kotwicowisko” nie tylko w parlamencie, sądzie czy na posterunku policji, obecna jest również w rodzinnych relacjach, w szpitalach, szkołach i na uniwersytetach. Lektura artykułu Hudzika prowokuje jednak także kilka pytań pod adresem francuskich dekonstrukcjonistów. Za jaką cenę dokonuje się firmowana przez nich teoretyczna emancypacja? Czy potrafili się oni przekonująco uporać ze wszystkimi dwuznacznościami, w jakie wplątany zostaje zgodnie z ich własnym ujęciem władzy teoretyk? Czy proponowana przez nich strategia oporu wobec władzy okazała się skuteczna? Próba odpowiedzi na te pytania niestety znacznie wykracza poza ramy niniejszego tekstu.

Artur Laska w swoim artykule powrócił do rozważań metodologicznych związanych ze specyfiką przedmiotu nauki o polityce. Podkreślił, że politolog musi zawsze uwzględniać dwa nieredukowalne wymiary polityki. Pierwszy z nich jest obiektywny, obejmuje „strukturalne i materialne składniki kultury, w tym 
również wytwory polityki" [Laska 2020: 168]. Drugi wymiar ma jednak charakter subiektywny, związany jest ze świadomością, strukturami znaczeń kierujących działaniami podmiotów polityki, tworzeniem narracji, na rzecz których się argumentuje i o które toczy się spory. Laska trafnie podkreślił, że skoncentrowanie się tylko na jednym wymiarze z pominięciem drugiego zawsze skutkuje redukcjonizmem [Laska 2020: 168]. Politolog, który dostrzega tylko obiektywny aspekt polityki, będzie w niej widział jedynie quasi-techniczną działalność podporządkowaną zupełnie regułom racjonalności instrumentalnej. Swoją rolę będzie zaś postrzegał jako eksperta, który oferuje usługi w zakresie lepszego administrowania. Inne niebezpieczeństwo związane ze ślepotą na którychś z dwóch wymiarów polityki to wąska specjalizacja, która choć często bywa obecnie postrzegana jako najlepszy wzorzec zawodowego sukcesu, to skutkuje naukowym przyczynkarstwem [Laska 2020: 179-180].

Co ciekawego do powiedzenia na temat przedmiotu badań politologów ma socjobiologia? Zdaniem Jarosława Noconia, reprezentuje ona rygorystyczny model nauk przyrodniczych, który otwiera interesujące perspektywy także w nauce o polityce. Kluczowe znaczenie dla socjolobiologii, a także innych nurtów ewolucjonizmu ma pojęcie „wyjaśnienia funkcjonalnego”. Nocoń podkreślił jednak, że interpretacje pojęcia funkcji w socjobiologicznych koncepcjach polityki można podzielić na trzy grupy: teleologiczne, deterministyczne i dialektyczne [Nocoń 2020: 185]. Pierwsza grupa - interpretacje teleologiczne - wiąże się z przyjęciem, że zachowania polityczne (np. ukierunkowane na interes grupowy) należy interpretować w świetle mechanizmów prowadzących do maksymalizacji ogólnej wartości przystosowawczej (inclusive fitness). Deterministyczne interpretacje funkcji usiłują wyjaśnić sferę polityczności jako określoną przez czynniki, takie jak geny i typy fenotypowe. Trzecia grupa, czyli dialektyczne interpretacje funkcji, jest być może najciekawsza, ponieważ pozwala na bardziej złożone i dwukierunkowe ujęcie związków między naturą i kulturą. Funkcja może w tym przypadku oznaczać zresztą zarówno relację eufunkcjonalną, jak i dysfunkcjonalną w stosunku do celu, jakim jest adaptacja do środowiska [Nocoń 2020: 190-192].

Numer zamykają dwa artykuły poświęcone historii Stanów Zjednoczonych Ameryki. W pierwszym z nich Terence Ball wykorzystuje ukute przez siebie pojęcie „śmiercionośnej hermeneutyki” (deadly hermeneutics) w odniesieniu do zaskakującej na pierwszy rzut oka postaci - Abrahama Lincolna. Jednak Lincoln podobnie jak wielu innych przywódców politycznych zdawał sobie sprawę z wagi tego, aby to jego interpretacja pewnych kluczowych tekstów stała się autorytatywna [Ball 2020: 199]. W przypadku Lincolna chodziło o rozpoczętą przezeń już w latach 50. XIX wieku próbę odczytania dwóch dokumentów: Deklaracji niepodległości Stanów Zjednoczonych i Konstytucji Stanów Zjednoczonych. Jego celem była interpretacja, która uzasadniałaby zniesienie niewolnictwa bez jednoczesnego dawania pretekstu amerykańskiemu Południu do secesji [Ball 2020: 199-206]. Po wybuchu wojny secesyjnej, już jako prezydent, Lincoln kontynuował swoje hermeneutyczne zabiegi, umiejętnie manewrując między różnymi 
grupami interesów. Kulminacją tych starań była słynna Przemowa gettysburska, w której dokonał bardzo śmiałej reinterpretacji toczącego się konfliktu. Lincoln przedstawił bowiem wojnę secesyjną jako zmagania, których stawką było spełnienie obietnicy amerykańskiej religii politycznej, obietnicy ucieleśnionej nie w Konstytucji, a w Deklaracji niepodległości [Ball 2020: 210-212].

Russel L. Hanson w ostatnim artykule przeanalizował z kolei spór pomiędzy konkurencyjnymi interpretacjami Konstytucji przedstawionymi przez Alexandra Hamiltona i Jamesa Madisona. Nie mogę tutaj omawiać szczegółów wspomnianej kontrowersji między dwoma ojcami założycielami. Należy jednak wspomnieć, że nie jest to kwestia mogąca interesować tylko historyków. W Stanach Zjednoczonych Ameryki istnieje bowiem wpływowa tradycja, zgodnie z którą Konstytucja powinna być interpretowana zgodnie z intencjami jej twórców ${ }^{5}$. Hanson udowodnił jednak w swoim tekście, że ani Hamilton, ani Madison nie uważali, iż to właśnie oryginalne zamiary postaci zaangażowanych w powstawanie Konstytucji powinny mieć w tej kwestii kluczowe znaczenie [Hanson 2020: 218]. Drugi wątek, który pojawia się w artykule Hansona, jest związany z dobrze znaną krytyką fakcji przeprowadzoną przez Madisona. Przysporzyła ona Madisonowi opinii polityka i teoretyka niezbyt przychylnego zasadzie suwerenności ludu. Hanson argumentuje jednak, że czwarty prezydent Stanów Zjednoczonych Ameryki zajmował znacznie bardziej subtelne stanowisko. Uważał on, że ponieważ to stany ratyfikowały Konstytucję, wola ludu wyrażona właśnie na poziomie stanowym powinna stanowić wytyczną zarówno w przypadku interpretacji Konstytucji, jak i jej ewentualnych zmian [Hanson 2020: 226-238]. Czyni to stanowisko Madisona bardziej demokratycznym niż mogłoby się wydawać prima facie.

Na koniec chciałbym poczynić kilka ogólnych uwag w odniesieniu do podejścia interpretacyjnego. Po pierwsze, bardziej uzasadnione byłoby tak naprawdę mówienie o wielu podejściach interpretacyjnych, które objąć można jednym terminem tylko za cenę daleko posuniętej abstrakcji. Ten wewnętrzny pluralizm może być zarówno źródłem siły i bogactwa, jak i słabości tego modelu uprawiania nauki. O ile zalety nie wymagają chyba szerszego komentarza, o tyle warto na chwilę zatrzymać się przy potencjalnych wadach. Konstruktywizm, hermeneuty$\mathrm{ka}$, antyfundacjonalizm, poststrukturalizm to pojęcia i nazwy o odmiennych zakresach. Umieszczanie ich w jednym nurcie przesłaniać może istniejące pomiędzy nimi różnice. Może również tworzyć wrażenie chaotycznego eklektyzmu i pogłębiać nieporozumienia, którymi i tak zdążyły już obrosnąć wspomniane terminy.

Po drugie, podejście interpretacyjne nie musi prowadzić do relatywizmu i zupełnej arbitralności w wyborze interpretacji. Jego logiczną konsekwencją nie musi być bodaj także odrzucenie klasycznego ujęcia prawdy. W pewnym sensie jednak naturalnym następstwem przyjęcia jego głównych założeń jest uznanie, że prawda osiągalna w nauce oznacza intersubiektywną zgodność. Jeśli bowiem przyjmiemy,

5 Osobny problem stanowi to, że nie jest bynajmniej jasne, kto dokładnie zalicza się do tego grona [Hanson 2020: 218]. 
że rzeczywistość nigdy nie jest nam dana w niezapośredniczony sposób, iż przedmiot i podmiot poznania naukowego nie są osobnymi i odizolowanymi od siebie substancjami, i że nieuchronnie konstruujemy przedmiot badania, wnosząc do niego różne elementy naszego subiektywnego i gatunkowego uposażenia, nasuwa się podejrzenie, że nigdy nie „przebijemy się” do prawdy obiektywnej. Mówiąc ściślej, nawet jeśli istnieje jakaś rzeczywistość sama w sobie i jedna z naszych interpretacji do niej przystaje (cokolwiek to znaczy), nigdy nie będziemy tego mogli stwierdzić na pewno.

Ostatnia kwestia dotyczy prognostycznych oczekiwań związanych z naukami społecznymi (w tym nauką o polityce). Źródłem niemałych kompleksów badaczy uprawiających te nauki jest to, że dostarczają one stosunkowo niewielu praw przypominających te, o których mówią nauki przyrodnicze, a w związku z tym w relatywnie niewielkim stopniu umożliwiają przewidywanie biegu wydarzeń. Otóż wydaje się, że jeśli przyjmiemy podejście interpretacyjne, trudno spodziewać się zmiany tego stanu rzeczy. W moim przekonaniu Charles Taylor słusznie stwierdził, że zgodnie z interpretacyjnym/hermeneutycznym modelem nauk społecznych dokładne przewidywanie jest radykalnie niemożliwe. Jest tak z kilku powodów: sfera ludzkich działań i interakcji nie tworzy zamkniętego systemu, w którym kontroli można byłoby poddać wszystkie zmienne, nie jest również możliwe mierzenie dokładności interpretacji w takim samym sensie, w jakim mierzeniu poddają swoje dane nauki przyrodnicze. Trzeci, najważniejszy powód jest związany jednak z tym, że jeśli człowiek rzeczywiście jest samookreślającym się zwierzęciem (self-defining animal), to oznacza to, że wraz ze zmianą sposobu rozumienia zmienia się również on sam. Nigdy nie można wykluczyć pojawienia się radykalnej pojęciowej innowacji. $Z$ tego zaś wynika, że być może w przyszłości zaczniemy rozumieć siebie i działać w sposób, którego obecnie nie jesteśmy w stanie antycypować [Taylor 1985: 56-57].

Wszystko to nie oznacza bynajmniej, że podejście interpretacyjne należałoby zarzucić. Zebrane w 4. numerze „Teorii Polityki” stanowią dowód na to, że może być ono wykorzystywane w płodny i interesujący sposób. Do jego najważniejszych walorów zalicza się to, iż: „Interpretacja wnosi do nauki o polityce walor epidygmatyczny - sprawia, że charakterystyczne elementy rzeczywistości »stają się zrozumiałe we współtworzeniu« [...], przez co możliwe okazuje się nie tylko precyzyjniejsze wyjaśnienie czy trafniejsze przewidywanie, ale przede wszystkim ukazanie politycznych sensów otaczającej rzeczywistości i sensu własnej w niej obecności” [Blok, Kołodziejczak 2020: 10]. 
Title: Interpretative Approach in Political Science - an Overview of No. 4 of "Teoria Polityki"

Abstract: The article presents an overview of No. 4 of the Polish scientific journal "Teoria Polityki" which was published in 2020. Each issue of the journal has a different thematic focus. The papers collected in No. 4 elucidate and exemplify variants of the interpretative approach understood as a general scientific model for political science.

Keywords: hermeneutics, interpretation, political science, explanation

\section{BIBLIOGRAFIA}

1. Anderson R.L. (2008), The Debate over the Geisteswissenschaften in German Philosophy, [w:] The Cambridge History of Philosophy 1870-1945, ed. T. Baldwin, Cambridge University Press, Cambridge, s. 221-234.

2. Arystoteles (2007), Etyka nikomachejska, thum. D. Gromska, Wydawnictwo Naukowe PWN, Warszawa.

3. Bachryj-Krzywaźnia M. (2016), Interpretacjonizm narratywistyczny. Filozoficzna geneza, zatożenia metodologiczne i potencjat analityczny, [w:] Liberalizm i teoria polityczna, red. Ł. Dulęba, J. Wiśniewski, Wydawnictwo Naukowe Wydziału Nauk Politycznych i Dziennikarstwa Uniwersytetu im. Adama Mickiewicza w Poznaniu, Poznań, s. 127-146.

4. Ball T. (2020), Lincoln's Deadly Hermeneutics, ,Teoria Polityki”, nr 4, s. 197-215. DOI: https:// doi.org/10.4467/25440845TP.19.024.11790.

5. Bevir M., Rhodes R.A.W. (2016), Interpretive political science: mapping the field, [w:] Routledge Handbook of Interpretive Political Science, ed. M. Bevir, R.A.W. Rhodes, Routledge, New York, s. 3-27.

6. Blok Z., Kołodziejczak M. (2020), Interpretacja w nauce o polityce-formy obecności, „Teoria Polityki", nr 4, s. 7-10.

7. Brożek P. (2020), Legal Interpretation: Towards a New Paradigm?, „Teoria Polityki”, nr 4, s. 79-92. DOI: https://doi.org/10.4467/25440845TP.19.017.11783.

8. Czajowski A. (2020), Wyjaśnianie empiryczne a wyjaśnianie interpretacyjne działań politycznych, „Teoria Polityki”, nr 4, s. 43-60.

9. Hanson R.L. (2020), Original Intent and Popular Government: A Madisonian Perspective, „Teoria Polityki”, nr 4, s. 217-240. DOI: https://doi.org/10.4467/25440845TP.19.025.11791.

10. Hudzik J.P. (2020), Władza i to, co politycznie nieokreślone: niewczesne rozważania o dekonstrukcji, „Teoria Polityki”, nr 4, s. 139-166. DOI: https://doi.org/10.4467/25440845 TP.19.021.11787.

11. Jabłoński A.W. (2020), Interpretacje w naukach społecznych - aspekty teoretyczne i metodologiczne, „Teoria Polityki”, nr 4, s. 11-30. DOI: https://doi.org/10.4467/25440845TP.19.013.11779.

12. Johnson R., Cuerton A., Kant's Moral Philosophy, https://plato.stanford.edu/entries/kant-moral/ [dostęp: 25.07.2020].

13. Kułakowska M. (2020), Interpretive Theories in Political Science, „Teoria Polityki”, nr 4, s. 31-41. DOI: https://doi.org/10.4467/25440845TP.19.014.11780.

14. Kurowska X. (2020), Interpretive Scholarship in Contemporary International Relations, „Teoria Polityki”, nr 4, s. 93-107. DOI: https://doi.org/10.4467/25440845TP.19.018.11784. 
15. Laska A. (2020), O niezbędności politologicznej interpretacji - subiektywność i narracyjność jako determinanty warsztatu politologa, „Teoria Polityki”, nr 4, s. 167-182. DOI: https://doi. org/10.4467/25440845TP.19.022.11788.

16. Nocoń J. (2020), Interpretacja funkcji w socjobiologicznych koncepcjach polityki, „Teoria Polityki”, nr 4, s. 183-195. DOI: https://doi.org/10.4467/25440845TP.19.023.11789.

17. Pierzchalski F. (2020), ,Zewnętrzność” interpretacji. Badanie polityki w ujęciu eksternalistycznym, „Teoria Polityki”, nr 4, s. 61-77.

18. Taylor Ch. (1985), Interpretation and the Sciences of Man, [w:] Ch. Taylor, Philosophy and the Human Sciences, Philosophical Papers 2, Cambridge University Press, Cambridge, s. 15-57.

19. Teichert D. (2020), Hermeneutics: Polity, Politics, and Political Theory in Gadamer's Philosophical Hermeneutics, „Teoria Polityki”, nr 4, s. 123-138. DOI: https://doi.org/10.4467/254 40845TP.19.020.11786.

20. Węgrzecki J. (2020), Teoria polityki - powszechność interpretacjonizmu na przykładzie rekonstrukcji, „Teoria Polityki”, nr 4, s. 109-122. DOI: https://doi.org/10.4467/25440845 TP.19.019.11785. 